\title{
Effect of Dazomet on Annual Bluegrass Emergence and Creeping Bentgrass Establishment in Putting Green Turf
}

\author{
Peter J. Landschoot, ${ }^{1}$ Bradley S. Park, Andrew S. McNitt \\ Department of Crop and Soil Sciences, The Pennsylvania State University, \\ University Park, PA 16802
}

\author{
Michael A. Fidanza \\ Division of Science, Berks-Lehigh Valley College, The Pennsylvania State \\ University, Tulpehocken Road, P.O. Box 7009, Reading, PA 19610
}

Additional index words. methylisothiocyanate, fumigation, turfgrass renovation

\begin{abstract}
Fumigation of annual bluegrass (Poa annua L.)-infested putting greens before seeding creeping bentgrass (Agrostis stolonifera L.) prevents stand contamination due to annual bluegrass seedling emergence. Dazomet is a soil fumigant labeled for use in putting green renovation; however, limited data are available on efficacy of dazomet controlling annual bluegrass seedling emergence following surface-applications. The objectives of this study were to determine the influence of rate and plastic covering of surface-applied dazomet on annual bluegrass seedling emergence in putting green turf; and safe creeping bentgrass seeding intervals following applications of dazomet to putting green surfaces. Treatments were applied in late summer to the surface of a 20-year-old stand of turf maintained as a putting green and plots were watered immediately after application and throughout each test period. Plastic-covered dazomet treatments had fewer annual bluegrass seedlings than noncovered dazomet treatments. Three plastic-covered dazomet treatments $\left(291,340\right.$, and $\left.388 \mathrm{~kg} \cdot \mathrm{ha}^{-1}\right)$ provided complete control of annual bluegrass seedlings during 2000 and 2001 . None of the noncovered dazomet treatments provided complete control of annual bluegrass seedling emergence. Results of the seeding interval experiment revealed that creeping bentgrass seedling development was not inhibited in both plastic-covered and noncovered dazomet treatments, when seeded 8, 10, 13, and 16 d after dazomet was applied to the turf surface. Results of this study demonstrate that dazomet, applied at rates $\geq 291 \mathrm{~kg} \cdot \mathrm{ha}^{-1}$ to the surface of a putting green in summer and covered with plastic for $7 \mathrm{~d}$, can control annual bluegrass seedling emergence. Chemical name used: tetrahydro-3,5-dimethyl-2H-1,3,5-thiadiazine-2-thione (dazomet).
\end{abstract}

The frequency of golf course putting green renovations has increased in the northern United States because of problems associated with annual bluegrass encroachment and releases of improved creeping bentgrass cultivars (Savini, 2003; Beard and Sifers, 1997). A popular means of renovating putting greens involves using methyl bromide (bromomethane) to kill existing turf and annual bluegrass seed in the soil, followed by seeding of creeping bentgrass. Whereas, this method has been successfully employed for many years, methyl bromide may be banned in 2005 for agricultural and turfgrass uses in the United States (Ristaino and Thomas, 1997; Unruh, 1998). An alternative fumigant for putting green renovation would be an advantage to golf clubs and superintendents wishing to renovate putting greens if methyl bromide becomes unavailable for use.

Dazomet is a granular soil fumigant that controls fungi, bacteria, nematodes, and weed seeds in soils (Fritsch and Huber, 1995; Harris, 1991). In moist soils, dazomet is degraded into several volatile intermediate products,

Received for publication 2 Oct. 2003. Accepted for publication 30 Jan. 2004.

${ }^{1}$ To whom reprint requests should be addressed; e-mail pj11@psu.edu. annual bluegrass seedling emergence compared to not covering treated turf, and is more practical for small areas (i.e., putting greens) than large areas, such as fairways (Park and Landschoot, 2003).

Dazomet does not provide selective control of grass seed germination and emergence; therefore, golf course superintendents must be certain that phytotoxic concentrations of MITC are not present near the surface of the putting green at the time of creeping bentgrass seeding. Appropriate intervals for seeding creeping bentgrass into putting greens following surface applications of dazomet must be determined so that sound seeding recommendations can be made.

The objectives of this study were to determine 1) the influence of rate and plastic covering of surface-applied dazomet on annual bluegrass seedling emergence in turf maintained as a golf course putting green, and 2) safe creeping bentgrass seeding intervals following surface applications of dazomet covered with plastic or not covered.

\section{Materials and Methods}

Experimental site description. Both of the experiments in this study were conducted at the Joseph Valentine Turfgrass Research Center in University Park, PA on a 20-yearold mixed stand of creeping bentgrass 'Penneagle' $(\approx 30 \%)$ and annual bluegrass $(\approx 70 \%)$ maintained as a putting green. The soil was a sandy loam (67\% sand, $29 \%$ silt, $4 \%$ clay) with a $\mathrm{pH}$ of $8.0, \mathrm{P}$ at $42.6 \mathrm{~kg} \cdot \mathrm{ha}^{-1}$, a cation exchange capacity of $13.0 \mathrm{cmol}$ charge $/ \mathrm{kg}$ soil, and exchangeable $\mathrm{K}$ at $0.7 \mathrm{cmol} / \mathrm{kg}$ soil. The surface of the putting green contained a $2.5-\mathrm{cm}$ noncompressed layer of mat (thatch and sand mixture). The stand was fertilized with Contec Starter Fertilizer 19-25-5 (The Andersons, Maumee, Ohio) at $48.8 \mathrm{~kg} \cdot \mathrm{ha}^{-1}$ of $\mathrm{N}$ in 2000, 2001, and 2002. Before the start of each experiment, the turf was irrigated to prevent drought stress and mowed daily with a reel mower at a height of $3.1 \mathrm{~mm}$. Clippings were collected in baskets and removed from the site. No herbicides (other than dazomet and glyphosate [N-(phosponomethyl)glycine]) were applied to the site during 2000, 2001, or 2002.

Effects of dazomet rate and plastic covering on annual bluegrass seedling emergence. This experiment was conducted during 2000 and 2001 on the previously described site. Glyphosate was applied to turf on entire test areas at $3.4 \mathrm{~kg} \cdot \mathrm{ha}^{-1}$ before treatment applications on 11 July 2000 and 10 July 2001. The existing turf was killed with glyphosate before dazomet treatment applications because preliminary tests (unpublished) showed that the two lowest rates of dazomet used in this experiment did not kill all of the established turf. Turf in the control plots was treated with glyphosate to facilitate accurate assessments of annual bluegrass emergence because this herbicide will not affect emergence.

On 25 July 2000 and 20 July 2001, the test areas were core-aerated using a John Deere Aercore 800 (Deere \& Co., Moline, Ill.). This 
unit was equipped with 1.6-cm-diameter tines positioned on $5.1-\mathrm{cm}$ centers that cored to a depth of $6.4 \mathrm{~cm}$. The cores were removed from the test areas and the holes were filled with a soil mix consisting of $80 \%$ sand : $20 \%$ peat (by volume). On 3 Aug. 2000 and 23 July 2001, a Ryan Mataway (Cushman Inc., Lincoln, Neb.) walk-behind vertical mowing unit equipped with vertical blades $2.5 \mathrm{~cm}$ apart was used to scarify the turf surface to a depth of $0.6 \mathrm{~cm}$. Immediately following scarification, the perimeters of plots designated to be covered with plastic were excavated using a trencher (model 28; Olathe Manufacturing Inc., Industrial Airport, Kan.). Each trench was 8.0 $\mathrm{cm}$ deep and $7.5 \mathrm{~cm}$ wide.

Treatments included dazomet applied to the turf surface at $0,194,291,340$, or $388 \mathrm{~kg} \cdot \mathrm{ha}^{-1}$ and covered with clear plastic sheets $(4.0 \mathrm{mil}$ thick); dazomet applied to the turf surface at the same rates and not covered. Treatments were arranged as a $5 \times 2$ factorial. The experimental design was a randomized complete block design with three replications. Plot size was $1.2 \times 1.8 \mathrm{~m}$ and each plot was surrounded by a $0.3-\mathrm{m}$ border.

Dazomet treatments were applied by hand using shaker jars on 5 Aug. 2000 and 25 July 2001. Following dazomet applications, $\approx 1.3$ $\mathrm{cm}$ of water was applied through an automatic irrigation system to entire test areas. Water was applied incrementally over about $60 \mathrm{~min}$ to allow infiltration into the soil and to prevent surface ponding and runoff. Immediately after watering, plastic sheets were placed over the four dazomet treatments and one nontreated control that were designated to be covered. The edges of each plastic sheet were placed in the previously excavated trenches and backfilled with sand. On 12 Aug. 2000 and 1 Aug. 2001, $7 \mathrm{~d}$ after treatment (DAT) with dazomet, the plastic sheets were removed from covered plots.

Following the initial irrigation application for each test, a post-treatment irrigation regime was used and consisted of two to three irrigation cycles each day with about $0.3 \mathrm{~cm}$ of water applied per cycle. The objective of this regime was to keep the soil surface moist between the date of application and the date on which seedlings were counted. Frequent irrigation created an environment conducive for annual bluegrass seed germination and presumably reduced losses of phytotoxic gases on noncovered plots, as stated on the dazomet product label (Basamid Granular, BASF AG, Ludwigshafen, Germany).

During the 26-d test period in 2000, daily air temperatures at the test site ranged from 28 to $8{ }^{\circ} \mathrm{C}$ (average daily high $=25^{\circ} \mathrm{C}$; average daily low $=15^{\circ} \mathrm{C}$ ) and the test area received a total of $20 \mathrm{~cm}$ of irrigation and rainfall. In 2001, daily air temperatures ranged from 35 to $11^{\circ} \mathrm{C}$ during the $27-\mathrm{d}$ test period (average daily high $=28^{\circ} \mathrm{C}$; average daily low $=18^{\circ} \mathrm{C}$ ) and the test area received a total of $28 \mathrm{~cm}$ of irrigation and rainfall.

On 30 Aug. 2000 (25 DAT) and 20 Aug. 2001 (26 DAT), annual bluegrass seedlings were counted in all plots. These dates were chosen because numerous seedlings emerged in some of the plots and evaluators would have experienced difficulty distinguishing among individual seedlings if counts were delayed for longer than 25 and 26 DAT. Some additional seedlings may have emerged in some plots after the counts were made. However, observations of the plastic-covered 291, 340, and $388 \mathrm{~kg} \cdot \mathrm{ha}^{-1}$ dazomet-treated plots and noncovered 340 and $388 \mathrm{~kg} \cdot \mathrm{ha}^{-1}$ dazomet-treated plots did not reveal any newly emerged seedlings up to one month after seedlings were counted.

Seedling counts were made by placing a $1.2 x$ 1.8 -m grid $\left(2.2-\mathrm{m}^{2}\right)$ over each plot and counting all seedlings within the grid. Seedling counts were subjected to a square root transformation before statistical analysis (Steel and Torrie, 1980). Transformed seedling counts were subjected to analysis of variance and means were separated using Fisher's protected least significant difference test at the 0.05 level of significance. The nontransformed seedling counts are presented in Table 2, but the statistical analyses are based on transformed data.

Safe seeding intervals of creeping bentgrass following dazomet applications. This experiment was conducted during 2001 and 2002 on the previously described experimental site. On 27 June 2001 and 26 June 2002, dazomet was applied to the individual test sites to kill the existing turf and prevent annual bluegrass from germinating. Annual bluegrass germination during this test would have interfered with creeping bentgrass ground cover and yield estimates. The dazomet was applied to each test site at $388 \mathrm{~kg} \cdot \mathrm{ha}^{-1}$ using a 0.9 -m-wide drop spreader (Gandy Co., Owatonna, Minn.). Immediately after application, each site received $1.3 \mathrm{~cm}$ of irrigation water and was covered with clear plastic sheets (4.0 mil thick) which were secured to the ground with steel pins. The plastic sheets were removed on 2 July 2001 and 1 July 2002 ( $5 \mathrm{~d}$ after treatment). To insure that the dazomet application did not interfere with the seedling interval experiment treatments, the test area was fumigated about 7 weeks before treatment applications in 2001 and 2002. Preliminary tests (unpublished) at this site indicated that creeping bentgrass seed germination was not inhibited when seeded 4 wk or more following application of dazomet at $388 \mathrm{~kg} \cdot \mathrm{ha}^{-1}$.

On 12 Aug. 2001 and 19 Aug. 2002, the test area was core-aerated and topdressed in a manner identical to that described in the previous experiment. On 22 Aug. 2001 and 20 Aug. 2002, the areas were scarified and trenches excavated as described in the previous experiment.

Following site preparation, each test area was divided into three replicate blocks, each block contained sixteen $1.2 \times 1.8$-m plots surrounded by 0.3 -m borders. Eight plots in each block were treated with dazomet at $388 \mathrm{~kg} \cdot \mathrm{ha}^{-1}$, and eight plots were not treated. Four of the eight plots treated with dazomet were covered with clear, plastic sheets (4 mil thickness), whereas the other four were not covered. Four of the eight nontreated plots were covered with clear plastic sheets, and the other four were not covered. Dazomet was applied with shaker jars on 24 Aug. 2001 and 22 Aug. 2002. Within 60 min of dazomet application, $1.3 \mathrm{~cm}$ of water was applied to the entire test area. Immediately after watering, plastic sheets were placed over the eight dazomet treatments and eight nontreated controls designated to be covered. The edges of each plastic sheet were placed in the trenches and backfilled with sand. On 31 Aug. 2001 and 29 Aug. 2002 (7 DAT) the plastic sheets were removed from all covered plots.

The seeding interval treatments consisted of 'Penn G-6' creeping bentgrass seeded at 48.6 $\mathrm{kg} \cdot \mathrm{ha}^{-1}$ on dazomet-treated and nontreated turf at $8,10,13$, and $16 \mathrm{~d}$ after dazomet was applied to the plots. Treatments were arranged as a $4 \times$ $2 \times 2$ factorial. The experimental design was a randomized complete block design with three replications. Penn G-6 seed was applied through shaker jars. Contec Starter Fertilizer (19-25-5) was distributed over each seeded plot using shaker jars at a rate of $49.0 \mathrm{~kg} \cdot \mathrm{ha}^{-1}$ of $\mathrm{N}$.

The soil surface was kept moist by using the post-treatment irrigation regime described in the previous experiment. During the 83-d test period in 2001, air temperatures ranged from 29 to $-2{ }^{\circ} \mathrm{C}$ (average daily high $=18^{\circ} \mathrm{C}$; average daily low $7^{\circ} \mathrm{C}$ ) and the test area received $44 \mathrm{~cm}$ of irrigation and rainfall. During the 74-d test period in 2002, air temperatures ranged from 33 to $-1{ }^{\circ} \mathrm{C}$ (average daily high $=23^{\circ} \mathrm{C}$; average daily low $=10^{\circ} \mathrm{C}$ ) and the test area received 45 $\mathrm{cm}$ of irrigation and rainfall.

Visual percent groundcover ratings were made for all seeding interval treatments in 2001 and 2002 at $22 \mathrm{~d}$ after the seeding date (DAS) of each respective treatment. A plot with complete turf cover and no visible soil or dead turf was considered $100 \%$ turf cover. Yields were assessed on 13 Nov. 2001 and 28 Oct. 2002, by collecting clippings from each plot using a 56.9-cm-wide reel mower bench-set at a cutting height $1.3 \mathrm{~cm}$. Clippings were collected from a $1.1-\mathrm{m}^{2}$ area in each plot, weighed, and recorded as fresh clipping yields. All data were subjected to analysis of variance and means were compared using Fisher's protected least significant difference test at the 0.05 level of significance.

\section{Results}

Effects of dazomet rate and plastic covering on annual bluegrass seedling emergence. Analysis of variance of data collected in 2000 and 2001 indicates that the main effects of dazomet treatment and plastic covering were significant $(P \leq 0.01)$ (Table 1$)$. All dazomet treatments reduced the number of emerged annual bluegrass seedlings compared to controls during both years of this experiment. Plasticcovered dazomet treatments resulted in fewer emerged annual bluegrass seedlings compared to noncovered treatments in 2000 and 2001.

Analysis of variance shows that a significant $(P \leq 0.01)$ dazomet treatment $\times$ plastic covering interaction occurred for data collected in 2000 but not in 2001 (Table 1). The interaction indicates that numbers of annual bluegrass seedlings decreased as the rate of dazomet increased for noncovered dazomet treatments; however, no differences occurred among dazomet rates with respect to seedling numbers for plastic-covered treatments in 2000.

When applied at 291, 340, and $388 \mathrm{~kg} \cdot \mathrm{ha}^{-1}$ 
Table 1. Analysis of variance of square root-transformed counts of annual bluegrass seedlings as influenced by dazomet treatment and plastic covering.

\begin{tabular}{lrcc}
\hline & \multicolumn{3}{c}{ Mean squares of annual bluegrass seedlings } \\
\cline { 2 - 4 } Source & df & 2000 & 2001 \\
\hline Replication & 2 & $10.78^{\mathrm{NS}}$ & $29.81^{\mathrm{NS}}$ \\
Dazomet (D) & 4 & $2512.00^{* * *}$ & $1909.87^{* * * *}$ \\
Plastic (P) & 1 & $792.56^{* * *}$ & $595.08^{* * *}$ \\
D $\times$ P & 4 & $110.16^{* *}$ & $6.71^{\mathrm{NS}}$ \\
Error & 18 & 15.41 & 47.89 \\
Corrected total & 29 & --- & -- \\
\hline
\end{tabular}

NS,******Nonsignificant or significant at $P \leq 0.01$ or 0.001 , respectively.

Table 2. Mean annual bluegrass seedlings (observed counts) from putting green turf treated with dazomet and covered with plastic or not covered.

\begin{tabular}{|c|c|c|c|c|c|}
\hline \multirow[b]{3}{*}{ Treatment } & \multirow{3}{*}{$\begin{array}{c}\text { Rate } \\
\left(\mathrm{kg} \cdot \mathrm{ha}^{-1}\right)\end{array}$} & \multicolumn{4}{|c|}{ Annual bluegrass seedlings $\left(2.2 \mathrm{~m}^{2}\right)$} \\
\hline & & \multicolumn{2}{|c|}{2000} & \multicolumn{2}{|c|}{2001} \\
\hline & & No plastic ${ }^{\mathrm{z}}$ & Plastic & No plastic & Plast \\
\hline Dazomet & 388 & $67 c^{y}$ & $0 \mathrm{~b}$ & $43 \mathrm{~b}$ & 0 \\
\hline Dazomet & 340 & $101 \mathrm{c}$ & $0 \mathrm{~b}$ & $96 \mathrm{~b}$ & 0 \\
\hline Dazomet & 291 & $127 \mathrm{c}$ & $0 \mathrm{~b}$ & $126 \mathrm{~b}$ & 0 \\
\hline Dazomet & 194 & $620 \mathrm{~b}$ & $0 \mathrm{~b}$ & $216 \mathrm{~b}$ & 22 \\
\hline Control & --- & $2664 \mathrm{a}$ & $2681 \mathrm{a}$ & $2678 \mathrm{a}$ & $1616 a$ \\
\hline
\end{tabular}

${ }^{\mathrm{z}}$ No plastic indicates that field plots were not covered with plastic following dazomet application, plastic indicates that field plots were covered with plastic sheets for seven days following dazomet application.

${ }^{y}$ Column numbers followed by the same letter are not significantly different as determined by Fisher's protected least significant difference test at $P=0.05$ on transformed data.

Table 3. Analysis of variance for percent ground cover and clipping yields of 'Penn G-6' creeping bentgrass seeded to dazomet and control plots in 2001 and 2002 at various intervals following dazomet application and removal of plastic covers ( $7 \mathrm{~d}$ after dazomet application).

\begin{tabular}{|c|c|c|c|c|c|}
\hline \multirow[b]{2}{*}{ Source } & \multirow[b]{2}{*}{ df } & \multicolumn{2}{|c|}{$\begin{array}{c}\text { Mean squares of } \% \\
\text { groundcover }(22 \text { DAS })^{z}\end{array}$} & \multicolumn{2}{|c|}{$\begin{array}{l}\text { Mean squares of } \\
\text { clipping yields }\end{array}$} \\
\hline & & 2001 & 2002 & 2001 & 2002 \\
\hline Replications & 2 & $46.31^{\mathrm{NS}}$ & $176.58^{\mathrm{NS}}$ & $122.91^{\mathrm{NS}}$ & $20584.26^{\mathrm{NS}}$ \\
\hline Dazomet (D) & 1 & $330.75^{\mathrm{NS}}$ & $1541.33^{\mathrm{NS}}$ & $6783.01^{* * *}$ & $2195084.71^{* * * *}$ \\
\hline Plastic (P) & 1 & $216.75^{\mathrm{NS}}$ & $192.00^{\mathrm{NS}}$ & $241.20^{\mathrm{NS}}$ & $1547.01^{\mathrm{NS}}$ \\
\hline Interval (I) & 3 & $5841.25^{* * * *}$ & $1117.67^{\mathrm{NS}}$ & $638.31^{*}$ & $334987.48^{\mathrm{NS}}$ \\
\hline $\mathrm{D} \times \mathrm{P}$ & 1 & $14.08^{\mathrm{NS}}$ & $487.37^{\mathrm{NS}}$ & $6.31^{\mathrm{NS}}$ & $69059.86^{\mathrm{NS}}$ \\
\hline $\mathrm{D} \times \mathrm{I}$ & 3 & $82.47^{\mathrm{NS}}$ & $1118.55^{\mathrm{NS}}$ & $676.84^{*}$ & $345668.16^{\mathrm{NS}}$ \\
\hline $\mathrm{P} \times \mathrm{I}$ & 3 & $219.25^{\mathrm{NS}}$ & $366.22^{\mathrm{NS}}$ & $94.18^{\mathrm{NS}}$ & $39694.12^{\mathrm{NS}}$ \\
\hline $\mathrm{D} \times \mathrm{P} \times \mathrm{I}$ & 3 & $140.47^{\mathrm{NS}}$ & $319.55^{\mathrm{NS}}$ & $93.81^{\mathrm{NS}}$ & $47475.65^{\mathrm{NS}}$ \\
\hline Error & 30 & 204.42 & 478.19 & 210.15 & 139781.45 \\
\hline
\end{tabular}

Corrected tota

47 $--$

${ }^{2}$ Days after seeding each respective seeding interval treatment.

NS, ${ }^{* * * * * * *}$ Nonsignificant or significant at $P \leq 0.05,0.01$, or 0.001 , respectively.

could be detected among dazomet treatments and controls at 22 DAS, regardless of plastic covering treatment, for treatments seeded 8,10 , 13 , and $16 \mathrm{~d}$ after dazomet was applied to the plots $(1,3,6$, and $9 \mathrm{~d}$ after plastic covers were removed from plots).

Whereas, a significant $(P \leq 0.001)$ seeding interval effect occurred for ground cover in 2001, no significant seeding interval effect was evident in 2002. The significant seeding interval effect in 2001 indicates that percent ground cover at 22 DAS declined in dazomet-treated plots from the 13 to the 16 DAT seeding interval treatments (Fig. 1). This was probably due to the effects of colder air and soil temperatures reducing creeping bentgrass growth for the last seeding interval treatment. Because temperatures were warmer and more constant throughout the 2002 test period compared to the 2001 test period, ground cover was not as strongly affected among the different seeding interval treatments.

Clipping yields were greater in 2002 than in 2001, presumably due to warmer air temperatures during the 2002 test period. Analysis of variance of clipping yield data collected on 13 Nov. 2001 and 3 Nov. 2002 indicate that the main effect of dazomet treatment was significant $(P \leq 0.001)$ in both years (Table 3$)$. The main effect of seeding interval was significant $(P \leq$ 0.05 ) in 2001, but not in 2002, whereas the main effect of plastic was not significant in either year. In 2001, clipping yields were greater in dazomet-treated plots than in control plots for the 8,10 , and 13 DAT seeding interval treatments, but no differences occurred between dazomettreated and control plots for the 16DAT seeding interval treatment (Fig. 2). In 2002, clipping yields were greater in dazomet-treated plots compared to controls for all seeding interval treatments (Fig. 3).

A significant $(P \leq 0.05)$ dazomet treatment by seeding interval interaction occurred for clipping yields during 2001, but not in 2002 (Table 3 ). This interaction indicates that clipping yields dazomet, plastic-covered dazomet treatments provided complete $(100 \%)$ control of annual bluegrass seedling emergence in 2000 and 2001 (Table 2). The plastic-covered $194 \mathrm{~kg} \cdot \mathrm{ha}^{-1}$ dazomet treatment provided complete control of annual bluegrass seedling emergence in 2000, but not in 2001. When applied at 291,340, and $388 \mathrm{~kg} \cdot \mathrm{ha}^{-1}$ dazomet, the noncovered dazomet treatments did not differ in numbers of emerged annual bluegrass seedlings in either year of the experiment. Whereas, none of these treatments provided complete control of seedling emergence, all produced $\geq 95 \%$ fewer seedlings than the noncovered controls during 2000 and 2001. The noncovered $194 \mathrm{~kg} \cdot \mathrm{ha}^{-1}$ dazomet treatment provided only $77 \%$ fewer annual bluegrass seedlings than noncovered controls in 2000, and $92 \%$ fewer seedlings in 2001.

Safe seeding intervals of creeping bentgrass following dazomet applications. Analysis of variance of percent ground cover data at 22DAS for each respective seeding interval treatment revealed that the main effects of dazomet treatment and plastic covering were not significant in 2001 and 2002 (Table 3). These results indicate that no differences in ground cover

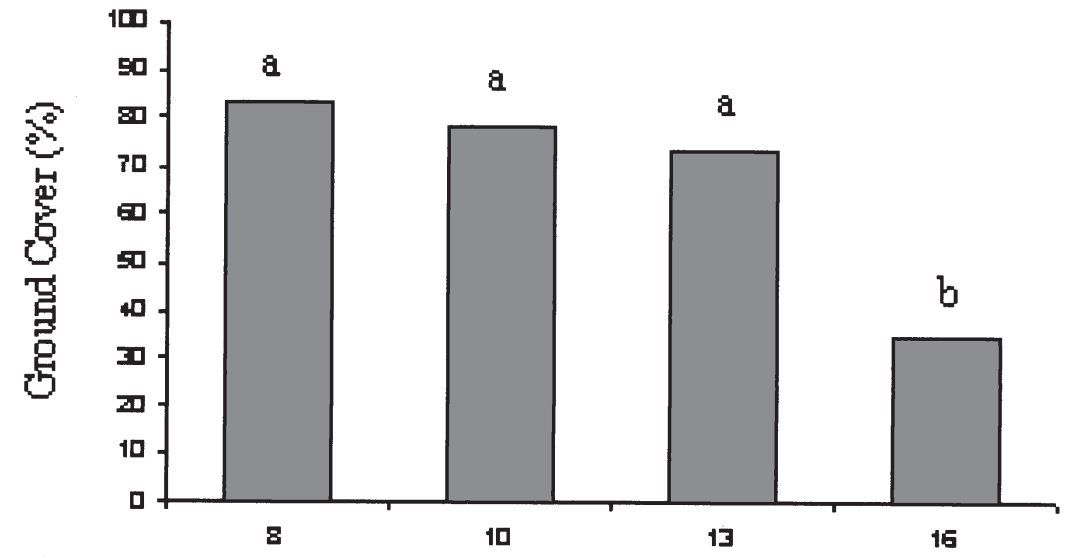

\section{Seeding Interval Treatment}

Fig. 1. Visual estimates of percent groundcover taken $22 \mathrm{~d}$ after seeding each respective seeding interval treatment $(8,10,13$, and $16 \mathrm{~d}$ after dazomet application on 24 Aug. 2001) with 'Penn G-6' creeping bentgrass in 2001. Because no significant dazomet and plastic treatment effects were found in 2001, data from the covered and noncovered dazomet and control treatments were pooled for seeding interval treatment. Different letters above a treatment comparison indicate a significant difference at $P \leq 0.05$ according to Fishers protected LSD test. 


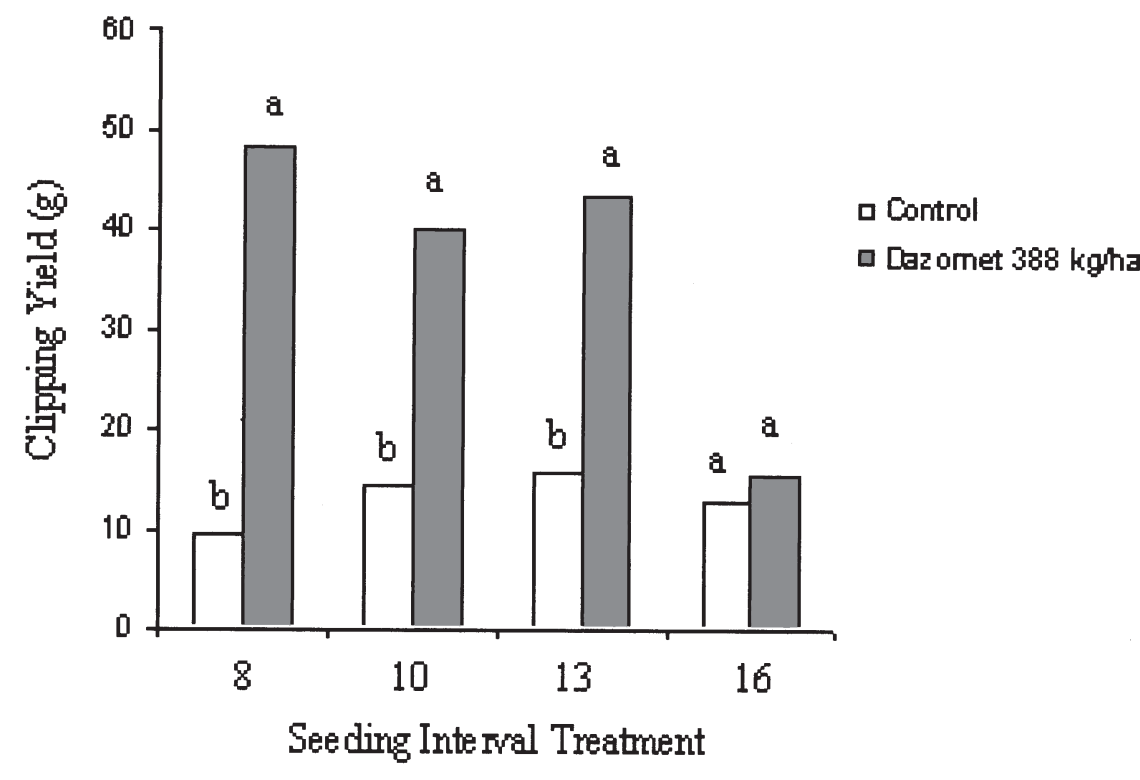

Fig. 2. Fresh weight clipping yields from plots treated with dazomet (24 Aug. 2001) and control plots seeded with 'Penn G-6' creeping bentgrass for seeding interval treatments of 8, 10, 13, and $16 \mathrm{~d}$ after dazomet application. No significant plastic covering effects were found in 2001; therefore, data from plastic-covered and noncovered treatments were pooled for dazomet and control treatments. Clippings were collected from all plots on 13 Nov. 2001. Different letters above a treatment comparison indicate a significant difference at $P \leq 0.05$ according to Fishers protected LSD test.

were greater for dazomet treatments compared to controls at 8,10 , and 13 DAT but not at 16 DAT in 2001 (Fig. 2.). This was likely due to cooler air temperatures slowing creeping bentgrass establishment during latter stages of the test period, thus negating the growth enhancement benefit from the dazomet.

\section{Discussion}

Surface applications of dazomet on annual bluegrass-infested turf growing in a sandy loam soil and maintained under putting green conditions reduced or eliminated emergence of annual bluegrass seedlings. These results are similar, but not identical, to those obtained by Park and Landschoot (2003) in studies using surface applications of dazomet on turf growing in a silt loam soil maintained as a golf course fairway. Park and Landschoot (2003) reported improved, but not complete, control of annual bluegrass seedling emergence for plastic-covered dazomet treatments when compared to noncovered dazomet treatments. In the present study, plastic-covered dazomet treatments at 291, 340, and $388 \mathrm{~kg} \cdot \mathrm{ha}^{-1}$ dazomet, provided complete control of annual bluegrass seedlings in putting green turf. One reason for the improved efficacy in the putting green study may be the lower quantity of viable seed near the soil surface (up to 2678 emerged annual bluegrass seedlings per $2.2 \mathrm{~m}^{2}$ ) than in Park and Landschoot's fairway study (up to 3914 emerged annual bluegrass seedlings per 2.2 $\mathrm{m}^{2}$ ). Another reason may be that the sandy loam soil present at the experimental site of the putting green study was more conducive to distribution of MITC and less likely to adsorb phytotoxic concentrations of MITC than the silt loam soil used in the fairway study. Gerstl et al. (1977) reported that coarse-textured soils $(<20 \%$ clay) allow more MITC to remain in the
Fig. 3. Fresh weight clipping yields from plots treated with dazomet (22 Aug. 2002) and control plots seeded with 'Penn G-6' creeping bentgrass in seeding interval treatments of $8,10,13$ and $16 \mathrm{~d}$ after dazomet application. Because no significan seeding interval effects were found in 2002, data from the four seeding interval treatments were pooled for dazomet treatments and controls. Clippings were collected from all plots on 28 Oct. 2002. Different letters above a treatment comparison indicate a significant difference at $P \leq 0.05$ according to Fishers protected LSD test.
Basamid Granular product label instructions do not provide detailed information on seeding intervals for creeping bentgrass following applications of dazomet to putting green surfaces, but suggest waiting 7 to $10 \mathrm{~d}$ between surface applications on lawns and seeding turfgrasses. Results of the seeding interval experiment show that creeping bentgrass can be seeded $8 \mathrm{~d}$ after a surface application of dazomet (or $1 \mathrm{~d}$ after removing plastic sheets that were used to cover treated turf for $7 \mathrm{~d}$ ) with no obvious detrimental effects to the newlyseeded turf. This finding is similar to results obtained by Park and Landschoot (2003) in which no detrimental effects were observed when creeping bentgrass was seeded $3 \mathrm{~d}$ after a dazomet application on fairway turf growing in a silt loam soil. Findings of the present study are based on a limited range of environmental and edaphic conditions, and more research should be conducted on safe seeding intervals following dazomet applications to determine the influence of soil texture, temperature, seeding depth, and water management on the inhibition of creeping bentgrass seed germination and establishment.

Clipping yield results from the seeding interval study indicate that a surge in creeping bentgrass growth occurred following dazomet applications. Increases in plant growth have been noted in other studies involving soil fumigants, including dazomet (Altman, 1970; Bernard and Hornby, 1982; Jenkinson et al., 1972; Park and Landschoot, 2003). In a study involving ${ }^{15} \mathrm{~N}$-labelled dazomet, Chabrol et al. (1982) found that dazomet increased maize dry matter yields from 7 to $13 \mathrm{t} \cdot \mathrm{ha}^{-1}$. The authors reported that this yield increase could not be explained entirely by the nitrogen contained in dazomet, and they attributed some of the yield increase to nitrogen released from microbial biomass killed by the dazomet.

Results of this study indicate that dazomet has potential to be an effective fumigant for putting green renovation in the northern United States, where annual bluegrass is the primary target weed. Findings of this study should be tempered by the fact that MITC diffusion, volatilization, adsorption, and degradation varies with soil texture, moisture, and temperature (Gan et al., 1999; Gerstl et al., 1977). Thus, it is possible that results obtained in the present




study will differ somewhat among the highly variable soil and environmental conditions that occur on golf courses throughout the northeastern United States. Potential users are encouraged to conduct preliminary tests to refine application rates and seeding intervals following dazomet applications before large scale use.

\section{Literature Cited}

Altman, J. 1970. Increased and decreased plant growth responses resulting from soil fumigation, p. 216-221. In: T.A. Toussoun, R.V. Bega, and P.E. Nelson (eds.). Root diseases and soil-borne pathogens. Univ. Calif. Press, Berkeley.

Beard, J.B. and S.I. Sifers. 1997. Bentgrasses for putting greens. Golf Course Mgt. 65(5):54-60.

Bernard, A.J. and D. Hornby. 1982. The effects of dazomet and nitrogen fertilizer on successive crops of maize (Zea mays L.) grown for either grain or forage. J. Agr. Sci. Camb. 98:7-15.

Branham, B.E., D.W. Lickfeldt, and M. Collins. 1994. 1993 turf weed control and management update. Proceed. 64 ${ }^{\text {th }}$ Annu. Mich. Turfgrass Conf. 23:1-9.

Chabrol M., D.S. Powlson, and D. Hornby. 1988. Uptake by maize (Zea mays L.) of nitrogen from ${ }^{15} \mathrm{~N}$-labelled dazomet, ${ }^{15} \mathrm{~N}$-labelled fertilizer and from the soil microbial biomass. Soil Biol. Biochem. 20:517-523.

Fritsch, H. J. and R. Huber. 1995. Basamid Granular-A halogen-free soil disinfestant. Acta Hort. 382:76-85.

Gan, J., S.K. Papiernik, S.R. Yates, and W.A. Jury. 1999. Temperature and moisture effects on fumigant degradation in soil. J. Environ. Qual. 28:1436-1441.

Gerstl, Z., U. Mingelgrin, and B. Yaron. 1977. Behavior of Vapam and MIT in soils. Soil Sci. Soc. Proc. 41:545-548.

Hardebeck, G.,Z. Reicher, and B.E. Branham. 2000. Optimizing the use of Basamid for Pоа аппиа control in fairway renovation. $2000 \mathrm{Annu}$. Rpt. Purdue Univ. Turfgrass Sci. Progr. p. 37-41.

Harris, D.C. 1991. A comparison of dazomet, chloropicrin, and methyl bromide as soil disinfestants for strawberries. J. Hort. Sci. 66:51-58.

Jenkinson, D.S., T.Z. Nowakowski, and J.D.D.
Mitchell. 1972. Growth and uptake of nitrogen by wheat and ryegrass in fumigated and irradiated soil. Plant Soil 36:149-158.

Lembright, H.W. 1990. Soil fumigation: Principles and application technology. Supplement to J. Nematol. 22:632-644.

Mappes, D. 1995. Spectrum of activity of dazomet. Acta Hort. 382:96-103.

Park, B.S. and P.J. Landschoot. 2003. Effect of dazomet on annual bluegrass emergence and creeping bentgrass establishment in turf maintained as a golf course fairway. Crop Sci. 43:1387-1394.

Ristaino, J.B. and W. Thomas. 1997. Agriculture, methyl bromide, and the ozone hole: Can we fill the gaps? Plant Dis. 81:964-977.

Savini, W. 2003. Putting green regrassing and so much more. USGA Green Sect. Rec. 41(2):8-10.

Steel, R.G.D. and J.H. Torrie. 1980. Principles and procedures of statistics: A biometrical approach. McGraw-Hill Book Co., New York.

Unruh, B.J. 1998. Methyl bromide ban is coming soon. Golf Course Mgt. 66(11):67-70. 